\title{
DO OUR LINKAGES TO OTHERS AND A SENSE OF LOSS WHEN WE LEAVE A COMMUNITY MEDIATE THE RELATIONSHIP BETWEEN OUR CAREER GOALS AND SUCCESS?
}

\author{
M. Todd Royle, Valdosta State University, U.S.A.
}

dx.doi.org/10.18374/JIMS-20-1.1

\begin{abstract}
This research examines the relationships between two types of career goals (i.e., self-selected goals and goals to which employees commit on behalf of their organizations), embeddedness (i.e., links and community/sacrifice) and career success (i.e., the objective and subjective). This research aims to extend organizational scholarship by demonstrating the mediating potential of embeddedness (i.e., linkages and sacrifice for leaving a community) on the relationship between goal setting and career satisfaction. The study tests hypotheses derived from data collected from 303 full-time working respondents in the southeastern United States. Analyses indicated that embeddedness links and community either fully or partially mediated the majority of the relationships between goal setting and career success. This research includes a discussion of the study's results, strengths, limitations and directions for future research.
\end{abstract}

Keywords: Goal Setting, Embeddedness, Career Success 